\title{
液体ロケット及び固体ロケット排出物がオゾン層に及ぼす影響の評価*1 Evaluation of the Effect of Exhausts from Liquid and Solid Rockets on Ozone Layer
}

\author{
山 極 芳 樹*2.石 牧 徹 哉*3 \\ Yoshiki Yamagiwa and Tetsuya Ishimaki
}

Key Words : Environment, Ozone Layer, Propulsion, Rocket Exhaust

\begin{abstract}
This paper reports the analytical results of the influences of solid rocket and liquid rocket exhausts on ozone layer. It is worried about that the exhausts from solid propellant rockets cause the ozone depletion in the ozone layer. Some researchers try to develop the analytical model of ozone depletion by rocket exhausts to understand its physical phenomena and to find the effective design of rocket to minimize its effect. However, these models do not include the exhausts from liquid rocket although there are many cases to use solid rocket boosters with a liquid rocket at the same time in practical situations. We constructed combined analytical model include the solid rocket exhausts and liquid rocket exhausts to analyze their effects. From the analytical results, we find that the exhausts from liquid rocket suppress the ozone depletion by solid rocket exhausts.
\end{abstract}

\section{1. 序論}

現在，打ち上げロケットには化学ロケットが使用されて いる.このロケットは, 大きな推力を得ることができるので 地球の大きな重力場に逆らって宇宙空間へ離脱するには適 しているが，推進薬の燃焼中，周辺気体と反応して $\mathrm{ClO}_{\mathrm{X}}$, $\mathrm{NO}_{\mathrm{X}}, \mathrm{HO}_{\mathrm{X}}, \mathrm{Al}_{2} \mathrm{O}_{3}$ を含む排出物を排出する。これらの 成分はオゾン層に影響を及ぼすと考えられ，その中でも特 に固体ロケットモータから大量に排出される $\mathrm{ClO}_{\mathrm{X}}$ は最も 影響が大きいことが指摘されている。将来，宇宙産業の発 展に伴って, ロケットの大型化や, 打ち上げ回数の増加が 進み, 現在とは比較にならない規模のオゾン破壊成分が地 球大気に排出されると予想され, その結果, 上り重大なオ ゾン減少が起こることが危惧される。したがって，今後，口 ケットには，ロケット排出物によるオゾン層への影響を最 小限に抑えるような設計もしくは運用形態が求められ，そ のためには，排出物放出後のオゾン層を正確に模擬しうる 信頼性の高い解析モデルを作成する必要がある。ロケット 排出物によるオン゙ン減少については, 今日まで何人かの研 究者によってモデル化が試みられてきた れのモデルも, 液体ロケット排出物についてはオゾン減少 にあまり影響がないとされ考慮されているものは皆無であ るが，スペース・シャトルや H-IIA のように打ち上げ時に 固体ロケットと液体ロケットを併用するものも多く, 両者 の干渉についても検討する必要があると考えられる.

\footnotetext{
*1 (C) 2009 日本航空宇宙学会

平成 19 年 10 月 30 日, 第 51 回宇宙科学技術連合講演会におい て発表. 平成 20 年 11 月 4 日原稿受理

$* 2$ 静岡大学工学部

*3 ヤマハモーターエンジニアリング (株)
}

本研究は, より信頼性及び沉用性の高いオゾン減少モデ ルの構築を目指し, 固体ロケットモータと液体ロケットエン ジン両方の排出物を考慮した結合モデルの作成を行ったも のである。そして，固体ロケット，液体ロケット，及び両者 を考慮した結合モデルのそれぞれで解析を行い，比較する ことで,オゾン減少における各排出物の影響評価を実施する.

\section{2. 理論}

2.1 ロケット排出物と周辺大気との反応過程 ロケット は燃料を高温で燃焼させ，ノズルから大量の排気物を排出 する。この排出物，及び排出物から影響を受けた領域は，口 ケットプルームと呼ばれる。第 1 図にロケットプルームの概 念図を示す，ロケットプルームは排出直後には高温であり， 周辺大気と混ざり合って光化学反応をしながら冷却される. この高温な領域で起こる反応を Hot-plume 反応と呼ぶ。そ れに対して, 周辺大気温度とほぼ等しい温度まで冷却された 領域での反応は Cold-plume 反応と呼ぶ. Hot-plume 反応 領域では主にオゾン破壞成分の生成が行われると考えられ る. それに対して, Cold-plume 反応領域では Hot-plume 反応によって生成されたオゾン破壊成分によるオゾン減少 反応が起こると考えられている.

2.2 支配方程式 上記のロケットプルーム中の粒子も 含め, 大気中に打ける気体成分 $i$ の数密度 $n_{i}\left[\right.$ 個 $\left./ \mathrm{cm}^{3}\right]$ の 時間変化は, 光化学反応と拡散の効果より, 以下の質量保 存の式で表される。

$$
\frac{\partial n_{i}}{\partial t}=P_{i}-L_{i}+K_{y y}\left(\frac{\partial^{2} n_{i}}{\partial x^{2}}+\frac{\partial^{2} n_{i}}{\partial y^{2}}\right)+K_{z z} \frac{\partial^{2} n_{i}}{\partial z^{2}}
$$

ただし， $P_{i}$ 及び $L_{i}\left[\right.$ 個 $\left./ \mathrm{cm}^{3} \cdot \mathrm{s}\right]$ は，後述 $(2.5$ 節）のよう 


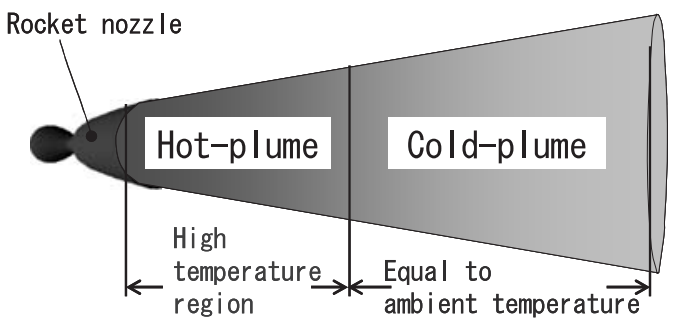

第 1 図 ロケットプルームの概念図

に周辺大気成分との反応及びアフターバーニング反応を考 慮した光化学反応による単位体積当たりの生成速度及び減 少速度である. 右辺第 3,4 項は拡散項であり, 次節で述べ るように水平方向と鉛直方向を別々に扱い，それぞれ別々 の拡散倸数; 水平方向拡散係数 $K_{y y}\left[\mathrm{~cm}^{2} / \mathrm{s}\right]$ 及び高度方向 拡散係数 $K_{z z}\left[\mathrm{~cm}^{2} / \mathrm{s}\right]$, を用いている。 また, 熱拡散の基 礎方程式は, 熱伝導のフーリエの法則及び，化学反応によ る生成熱により次式のように表される。

$$
\frac{\partial T}{\partial t}=\frac{Q}{c_{p} C}+\left(\kappa_{f}+\varepsilon_{h}\right)\left(\frac{\partial^{2} T}{\partial x^{2}}+\frac{\partial^{2} T}{\partial y^{2}}\right)
$$

ただし，T[K] は気体温度， $\kappa_{f}\left[\mathrm{~cm}^{2} / \mathrm{s}\right]$ は熱拡散率， $\varepsilon_{h}\left[\mathrm{~cm}^{2} / \mathrm{s}\right]$ は渦熱拡散率, $Q\left[\mathrm{~kJ} / \mathrm{cm}^{3} \cdot \mathrm{s}\right]$ は化学反応による 発熱吸熱速度, $c_{p}[\mathrm{~kJ} / \mathrm{mol} \cdot \mathrm{K}]$ は比熱, $C\left[\mathrm{~mol} / \mathrm{cm}^{3}\right]$ はモル 濃度である。

2.3 拡散係数 排出直後の Hot-plume 反応領域中は, 非常に強い乱流であると考えられ，渦拡散が支配的である. 洞拡散は乱流の強さによって決定されるので, 実際の拡散に 合うように決定することが重要である。したがって, Hotplume 反応領域中の水平方向拡散係数 $K_{y y}$ については, こ こでは Beiting の研究9) を参考に，プルームの観測に基づ いた排出直後のプルームの拡散係数のスケール依存性を基 にモデル化を行い

$$
K_{y y}=b R
$$

とした。ここで, $R$ はプルームの半径, $b$ はスケールパラ メータで

$$
b=85+7.9 \times(h-18)[\mathrm{cm} / \mathrm{s}]
$$

と表される， $h$ は高度 $[\mathrm{km}]$ である.

プルームが拡散した Cold-plume 反応領域での拡散係数 は，第 2 図に示す成層圈中での雲等の観測結果 ${ }^{10)}$ に基づき 決定した。ただし，第 2 図に示すように水平方向拡散係数 $K_{y y}$ は大きな幅（黒塗りの領域）を持っている. 本研究で は，口ケット排出物によるオゾン減少の潜在性を示すため, $K_{y y}$ の下限值に㧍ける水平方向拡散係数を用いることとす る.すなわち，

$$
K_{y y}[t]=5.00 \times t^{1.45}\left[\mathrm{~cm}^{2} / \mathrm{s}\right]
$$

とした.

Hot-plume 領域から Cold-plume 領域への水平方向拡散 係数の移行条件は，プルーム成分の数密度で判断する。プ

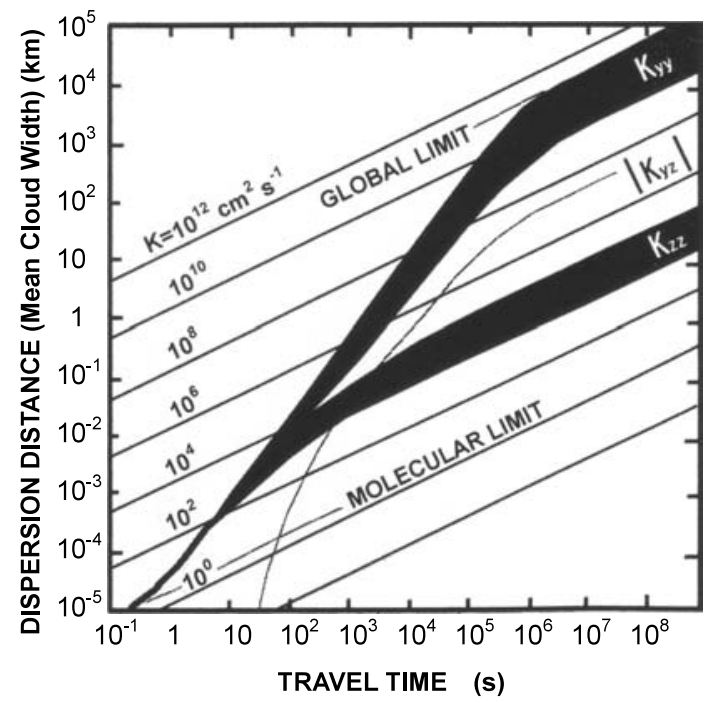

第 2 図 拡散距離と時間を関数とした成層圏中での 水平方向拡散係数 ${ }^{10)}$

ルーム成分の数密度が周辺大気中の同成分と比較して大き い場合は, プルームの分圧が周辺と比較して大きいので, Hot-plume 領域での水平方向拡散倸数を用いることとし た. 判定条件としては以下のようにした.

$$
\frac{n_{\text {plume }}[R=0, t]}{n_{\text {plume }}[R=\infty, t]}=1.1
$$

Hot-plume 領域での水平方向拡散係数から Cold-plume 領域の拡散係数に移行する場合, 直接移行させると, 水平 方向拡散係数が時間もしくはプルームの半径に対し不連続 となってしまう。 そこで, 水平方向拡散係数の遷移領域と して, Hot-plume 領域での水平方向拡散係数終了時の值を Cold-plume 領域での水平方向拡散係数が上回るまで用い ることとした。

高度方向拡散係数 $K_{z z}$ は, 島崎11) によるモデルの值を 使用した。ただし，排出直後から高度方向拡散係数に達す るまでの拡散は水平方向拡散係数を用いた。

2.4 熱拡散率と渦熱拡散率 熱拡散率 $\kappa_{f}$ は次式で表さ れる。

$$
\kappa_{f}=\frac{\lambda_{f}}{\rho c_{p}}
$$

ここで， $\lambda_{f}$ は熱伝導率 $[\mathrm{W} / \mathrm{m} \cdot \mathrm{K}]$ である． $\kappa_{f}$ は温度によっ て変化するので, 本研究では常圧下の気体の物性值 ${ }^{21}$ から 直線近似で与えた。

熱拡散と分子拡散には相似性があり，このことは乱流の 場合にも言うことができる. 熱拡散率と分子拡散率の比で あるルイス数 Le は, 熱拡散の媒体が空気の場合, 約 0.9 1.2 の範囲をとる. そこで, 本研究では $L e \fallingdotseq 1$ とし, 乱流 であるプルームでも相似であると考え $\varepsilon_{h} \fallingdotseq K_{y y}$ とする。

2.5 光化学反応 前述のように, 式 (1) 中の生成及び減 少項は光化学反応によるものであるが，化学反応速度係数 は温度依存性があるので, Hot-plume と Cold-plume 反応 で異なる化学反応式を選定する. Hot-plume 反応における 化学反応には， $\mathrm{O}, \mathrm{O}_{2}, \mathrm{O}_{3}$ の解離・結合のみを考慮した反 
第 1 表 解析モデルで考慮する気体成分

\begin{tabular}{|c|c|c|c|c|c|}
\hline \multicolumn{2}{|c|}{ No. } & \multicolumn{2}{|c|}{ No. } & \multicolumn{2}{|l|}{ No. } \\
\hline 1 & $\mathrm{O}$ & 10 & $\mathrm{NO}$ & 19 & $\mathrm{Cl}_{2} \mathrm{O}_{2}$ \\
\hline 2 & $\mathrm{O}\left({ }^{1} \mathrm{D}\right)$ & 11 & $\mathrm{NO}_{2}$ & 20 & $\mathrm{HCl}$ \\
\hline 3 & $\mathrm{O}_{2}$ & 12 & $\mathrm{NO}_{3}$ & 21 & $\mathrm{CH}_{4}$ \\
\hline 4 & $\mathrm{O}_{3}$ & 13 & $\mathrm{~N}_{2}$ & 22 & $\mathrm{CH}_{3}$ \\
\hline 5 & $\mathrm{OH}$ & 14 & $\mathrm{~N}_{2} \mathrm{O}_{5}$ & 23 & $\mathrm{CO}$ \\
\hline 6 & $\mathrm{H}$ & 15 & $\mathrm{Cl}$ & 24 & $\mathrm{CO}_{2}$ \\
\hline 7 & $\mathrm{H}_{2}$ & 16 & $\mathrm{Cl}_{2}$ & 25 & $\mathrm{HNO}_{3}$ \\
\hline 8 & $\mathrm{H}_{2} \mathrm{O}$ & 17 & $\mathrm{ClO}$ & 26 & $\mathrm{ClONO}_{2}$ \\
\hline 9 & $\mathrm{HO}_{2}$ & 18 & $\mathrm{ClO}_{2}$ & & \\
\hline
\end{tabular}

応である純酸素反応 (チャップマン反応) のほかに, 排出物 成分や背景大気成分から考慮して, $\mathrm{ClO}_{\mathrm{X}}$ 反応, $\mathrm{NO}_{\mathrm{X}}$ 反応, $\mathrm{HO}_{\mathrm{x}}$ 反応に関する反応式を選定する。 さらに, $\mathrm{CO} ゃ \mathrm{H}_{2}$ の 燃焼反応を中心としたアフターバーニング反応も考慮する.

また，Cold-plume 反応に㧍ける光化学反応式は，オゾ ン減少反応を中心とした純酸素反応及び $\mathrm{ClO}_{\mathrm{X}}$ 反応, $\mathrm{NO}_{\mathrm{X}}$ 反応, $\mathrm{HO}_{\mathrm{X}}$ 反応を中心に考慮する. 光解離反応式は解析高 度を考慮して, 約 $200 \mathrm{~nm}$ 以上の波長で解離する反応を選 定する。その結果, 本研究では, 第 1 表に示す 26 種の気 体成分（後述のロケット排出物を含む）を考慮し，14 種の 光解離反応, 及び 39 種の均一系の化学反応を, データベー ス13 15) を基にモデル化した。

\section{3. 解 析 条 件}

3.1 解析対象 解析対象は, H-IIA ロケットのメイン エンジン，及び固体ロケットブースターとする．H-IIA ロ ケットのメインエンジンの排出物量等のデータは文献 16) より引用した。固体ロケットブースターについては，H-IIA 自体のデータはないので, H-IIA の SRB-A と同様の固体 ロケットモータである TitanIV の SRM をモデルにした Zittel の文献) より引用した。

本研究に打いて考慮するロケットの排出物成分は, 過去 のモデルの解析結果においてオゾン層との反応に重要とさ れている第 2 表に示す 8 種類とする.

3.2 解析モデル 本解析に扔ける解析モデルの 2 次元 平面の概略図を第 3 図に，その解析領域の設定条件を第 3 表に示す. $I$ 方向, $J$ 方向の格子間隔 $\mathrm{d} x, \mathrm{~d} y$ は表に示すと おりである。

本解析では, Hot-plume 反応領域と Cold-plume 反応 領域とでは影響範囲が大きく異なるため，上に示すように Phase1, Phase2, Phase3 と格子間隔を変化させ計算を行 j. Phase1, Phase2 を Hot-plume 反応領域, Phase 3 を Cold-plume 反応領域とする。この 2 次元平面モデルを高 度 $h=18 \sim 40 \mathrm{~km}$ まで $1 \mathrm{~km}$ ごとに合計 23 層分解析を行 j (第 4 図).

Rocket plume の配置は, Hot-plume 反応領域では，解 析モデルの中心にノズル形状やノズル位置を考慮して配置す る. ロケット排出物の格子への初期配置は H-II ロケットエ ンジンを参考にして行う. H-IIA ロケットは, 直径 $1.7 \mathrm{~m} の$ 液体ロケットエンジン（LE-7A）の両サイドに, 直径 $2.5 \mathrm{~m}$ の 2 基の固体ロケットブースター (SRB) が接続している
第 2 表 解析モデルで考慮するロケット排出物成分

\begin{tabular}{cllcll}
\hline No. & & & No. & \\
\cline { 1 - 2 } \cline { 5 - 6 } & $\mathrm{CO}$ & & 5 & $\mathrm{HCl}$ \\
2 & $\mathrm{CO}_{2}$ & & 6 & $\mathrm{H}_{2}$ \\
3 & $\mathrm{Cl}$ & & 7 & $\mathrm{H}_{2} \mathrm{O}$ \\
4 & $\mathrm{H}$ & & 8 & $\mathrm{~N}_{2}$ \\
\hline
\end{tabular}

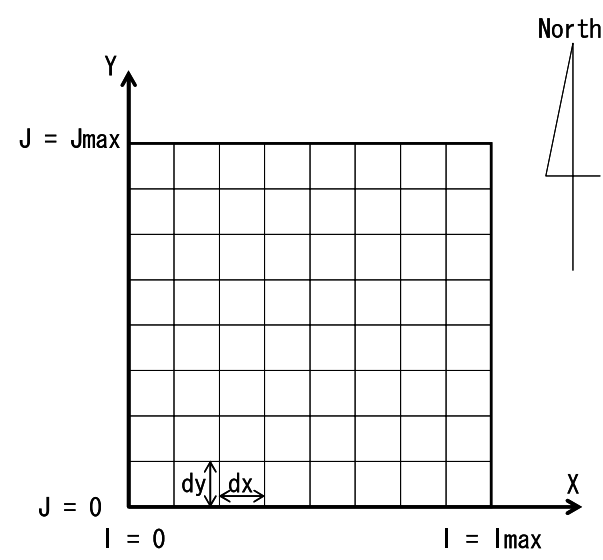

第 3 図 解析モデルの 2 次元平面計算領域

第 3 表 解析領域の設定

\begin{tabular}{clrrc}
\hline & & Phase1 & Phase2 & Phase 3 \\
\hline \multirow{2}{*}{ Grid } & $\mathrm{d} x[\mathrm{~m}]$ & 1 & 20 & 1000 \\
interval & $\mathrm{d} y[\mathrm{~m}]$ & 1 & 20 & 1000 \\
& $\mathrm{~d} z[\mathrm{~m}]$ & 1000 & 1000 & 1000 \\
\hline Maximum & $I_{\max }$ & 180 & 150 & 50 \\
grid & $J_{\max }$ & 180 & 150 & 50 \\
number & $K_{\max }$ & 22 & 22 & 22 \\
\hline
\end{tabular}

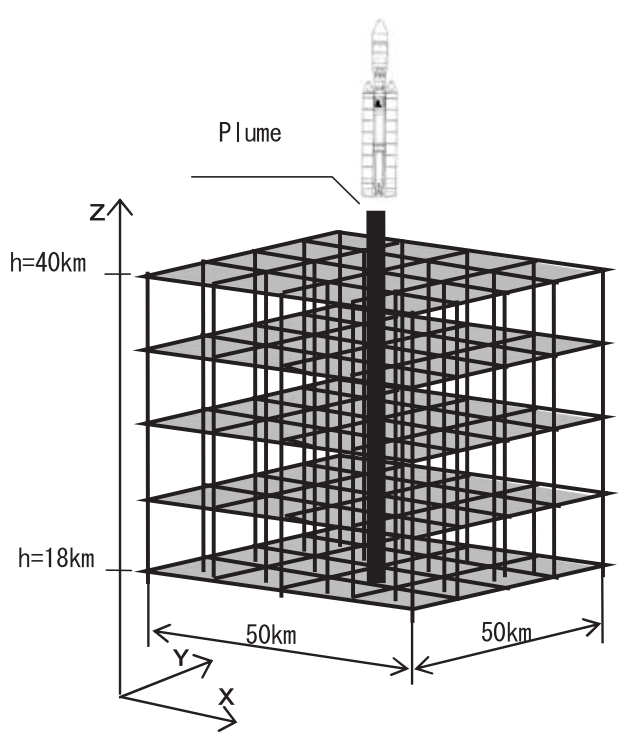

第 4 図 解析の 3 次元計算領域とロケット軌跡

という機体構成となっている17). 液体ロケットエンジン及 び固体ロケットブースターの直径がそれぞれ， $1.7 \mathrm{~m} ， 2.5 \mathrm{~m}$ であることにより，ロケット排出物の初期配置は，簡略化の ため第 5 図のと扔りとした。ただし，“1”，“0.5”，“0.75”， “ $0.375 ”, “ 0.25 ”$ は初期排出物数密度の比率である. 最も 初期密度が多い場所を “1”とし，そこから円形のノズルを 


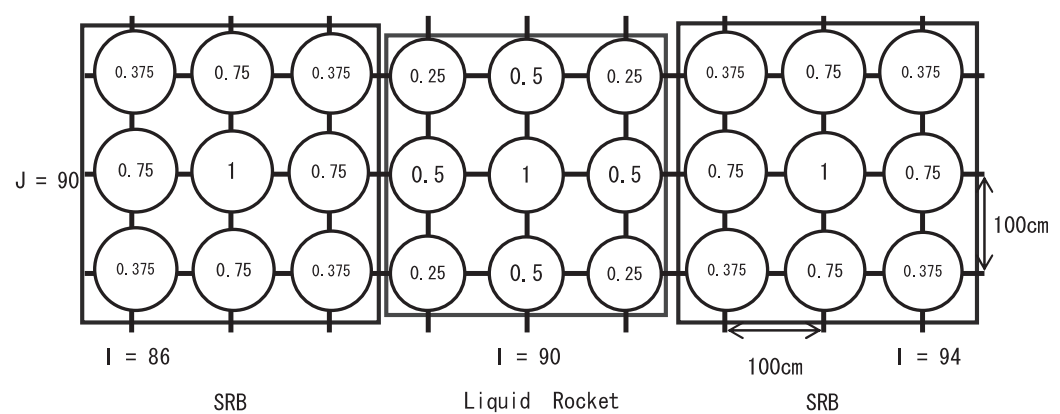

第 5 図 ロケット排出物の初期配置

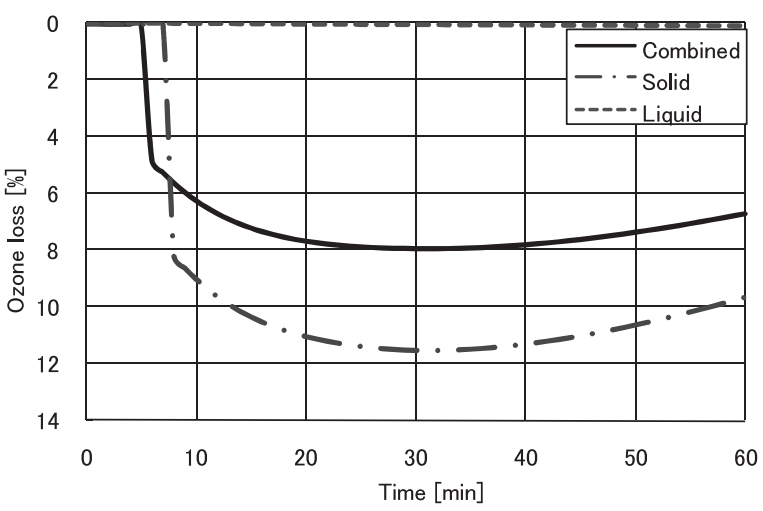

第 6 図 固体ロケット排出物のみと固体ロケット，液体ロケット 排出物両者を考慮した場合での最大オゾン層減少の比較

再現するように比率を変化させた. また, 固体ロケット排 出物モデルと液体ロケット排出物モデルで比率が異なるの はノズル直径が異なるためである。

また，ノズル出口温度はJAXA の文献 17) をもとに液体 ロケットモデル，固体ロケットモデルをそれぞれ $1500 \mathrm{~K}$, $3000 \mathrm{~K}$ とし，これを初期条件として計算を行う. 数值計算 方法としてオイラーの陰解法を用いる．境界条件としては, 自由流出境界条件を用いた。

解析では，排出物速度，及び風の影響は考慮しない。 た，固体ロケット排出物中には多くのアルミナ粒子を含ん でいるが，過去に本研究室で行われた研究8) ではアルミナ 粒子がオゾン層に及ぼす影響は少ないことが確認されてい るため, 本解析においては計算時間短縮も兼ねて考慮しな いことにした。

\section{4. 解析結果・考察}

第 6 図は固体ロケット排出物, 液体ロケット排出物, 及び 両者を考慮した結合モデル，それぞれにおける高度 $18 \mathrm{~km}$ から $40 \mathrm{~km}$ までを積算したオゾン最大減少率の時間履歴で ある.また, 第 7,8 図は固体ロケット, 液体ロケット両排 出物を考慮した場合及び固体ロケット排出物のみを考慮し た場合の, 高度 $18 \mathrm{~km}$ におけるロケット打ち上げ 60 分後に おけるオゾン数密度分布である。まず，第 6 図からは，液体 ロケット排出物のみの場合は，オゾン減少がほぼ見られな いが，固体ロケット排出物のみの場合及び固体ロケット，液 体ロケット排出物の両者を考慮した場合には，10\%前後の

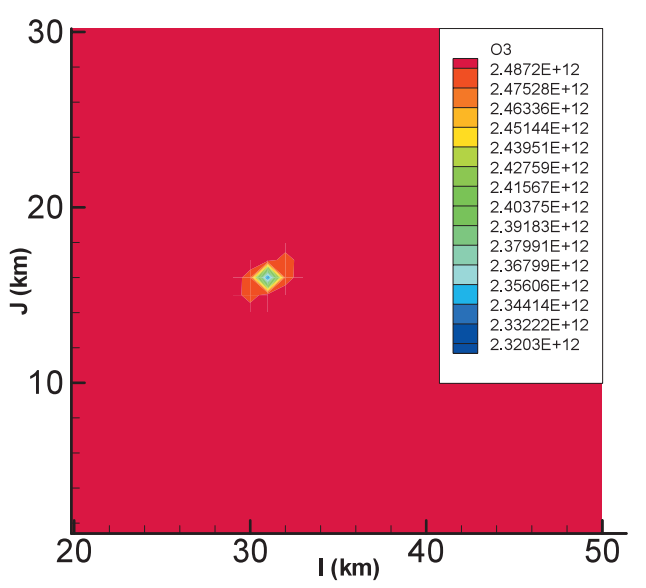

第 7 図 固体ロケット，液体ロケット排出物両者を考慮したときの オゾン密度分布（高度 $18 \mathrm{~km}$ ，排出後 60 分）

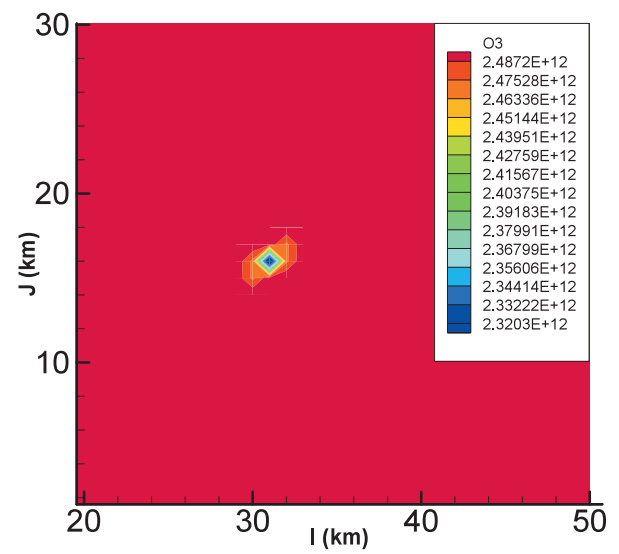

第 8 図 固体ロケット排出物のみを考慮したときのオゾン密度分布 (高度 $18 \mathrm{~km}$, 排出後 60 分)

オゾン減少が生ずることがわかる。しかしながら，固体口 ケット, 液体ロケット排出物の両者を考慮した場合は, 固体 ロケット排出物のみの場合よりもオゾン減少が少なく, 本 ケースでは固体ロケット排出物のみの場合に比べて 3 割程 度もオゾン減少を抑制していることがわかる.さらに，第 7 図と第 8 図を比較してみると, 液体ロケット排出物の存在 により，オゾン減少領域も固体ロケット排出物のみの場合 に比べて小さくなっていることがわかる，したがって，液 体ロケットと固体ロケットを併用する場合, 液体ロケット 排出物に含まれる成分はオゾン減少を抑制する働きがあり, 


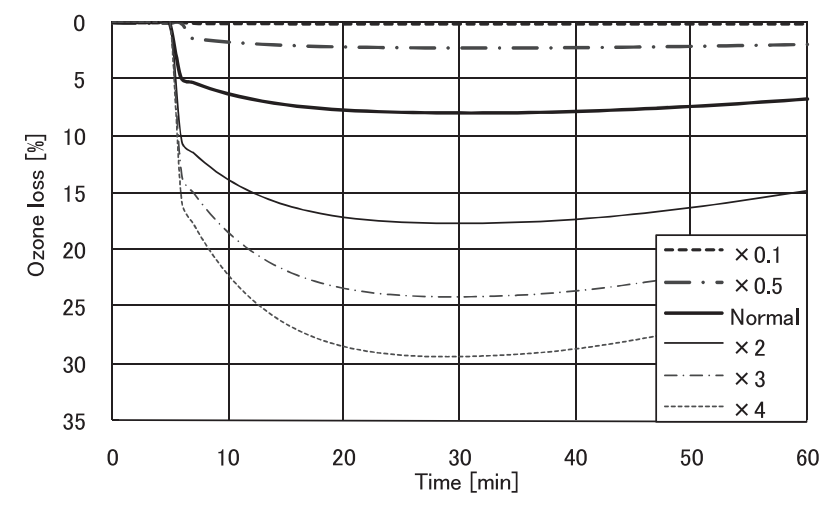

第 9 図 $\mathrm{HCl}$ の比率を変化させたときのオゾン損失の変化の比較

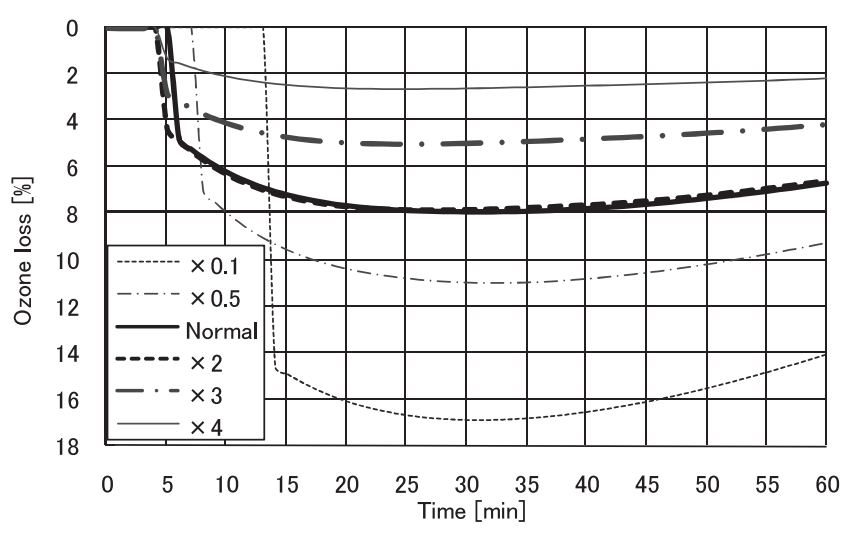

第 10 図 $\mathrm{H}_{2}$ と $\mathrm{H}_{2} \mathrm{O}$ の比率を変化させたときのオゾン損失の変化の 比較

その排出物がオゾン減少に及ぼす影響を評価するには，液 体ロケット排出物の効果は無視できないと考えられる。

では，ロケット排出物のどの成分がオゾン層減少に主要 な役目を果たし，どの成分がそれを抑制するのかを特定す るために, 各主要成分の割合を変えて調べた結果を以下に 示す.

第 9 図は $\mathrm{HCl}$ の比率を従来の排出量から $0.1,0.5,2,3$, 4 倍とそれぞれ変化させて解析を行った結果である. 図を 見ると $\mathrm{HCl}$ の排出量に比例してオゾン減少も大きくなって いくのがわかる。このことより，オゾン減少は固体ロケッ 卜排出物に含まれる $\mathrm{HCl}$ が周辺大気等と反応して生成され る $\mathrm{Cl}$ が主な原因であり，そのオゾン減少量は $\mathrm{HCl}$ の排出 量に比例すると考えられる. 第 10 図は $\mathrm{H}_{2}, \mathrm{H}_{2} \mathrm{O}$ の両者に ついて, 排出物量を $0.1,0.5,2,3,4$ 倍と変化させて解 析を行った結果である. 排出物量を 2 倍に変化させた場合 は従来の場合とほぼ変化が見られないが, そのほかの倍率 に変化させた場合においては, $\mathrm{H}_{2}, \mathrm{H}_{2} \mathrm{O}$ の排出物量が多い ほうがオゾン減少を抑制する傾向が見られる. $\mathrm{H}_{2}, \mathrm{H}_{2} \mathrm{O}$ も しくはこれらの反応物はオゾン減少を抑制する効果があり, オゾン減少の抑制につながったのではないかと考えられる。

\section{5. 結 論}

信頼性及び汎用性の高いオゾン減少モデルの構築を目指
して固体ロケットモータと液体ロケットエンジン両方の排 出物を考慮した結合モデルの作成を行った。解析結果から, 液体ロケット排出物は, 固体ロケット排出物によるオゾン の減少を抑える効果があることがわかった。したがって, 固 体ロケット作動時には, 特にオゾン層通過時においては, 液 体ロケットとの併用が好ましいと考えられる。

\section{参 考 文 献}

1) Ross, M.: Local Effects of Solid Rocket Motor Exhaust on Stratospheric Ozone, J. Spacecraft Rockets, 33 (1996), pp. 144-153.

2) Bernnet, R. R., Barnes, M. W., McDonald, A. J. and Hinshaw, J. C.: Chemical Rocket and the Environment, Aerospace America, 29 (1991), pp. 32-36.

3) Denison, M. R., Lamb, J. J., Bjorndahl, W. D., Woug, E. Y. and Lohn, P. D.: Solid Rocket Exhaust in the Stratosphere, J. Spacecraft Rockets, 31 (1994), pp. 435-442.

4) Brady, B. B. and Martin, L. R.: Modeling Solid Rocket Booster Exhaust Plume in the Stratosphere with SURFACE CHEMKIN, The Aerospace Corp., TR-95(5231)-9, 1995.

5) Smith, T. W. and Edwards, J. R.: Summary of the Impact of Launch Vehicle Exhaust and Deorbiting Space and Meteorite Debris on Stratospheric Ozone, U.S. Air Force Space and Missile Systems Enter Environmental Management Branch SMC/AXFV, Contract F09603-95-D-0176-0007, 1999.

6) Zittel, P. F.: Computer Model Predictions of the Local Effects of Large, Solid-Fuel Rocket Motors on Stratospheric Ozone, The Aerospace Corp., TR-94(4231)-9, 1994.

7）竹中信一，山極芳樹：固体ロケット排出物によるオゾン層との干 渉問題の 3 次元モデル化に関する研究, 宇宙技術, 3 (2004), pp. $1-10$.

8) 小林端人, 山極芳樹, 大津広敬: 固体ロケット排出物のオゾン層 との干渉モデルの改善に関する研究，平成 17 年度宇宙輸送シン ポジウム論文集, 2006, pp. 29-32.

9) Beiting, E. J.: Stratospheric Plume Dispersion: Measurements from STS and Titan Solid Rocket Motor Exhaust, The Aerospace Corp., TR-99(1306)-1, 1999.

10) Danielson, E. F. and Louis, J.: Transport in the Stratosphere, The Upper Atmosphere and Magnetosphere, National Academy of Sciences, Washington, DC, 1977, pp. 141155.

11) 島崎達夫: 成層圈オゾン, 第 2 版, 東京大学出版会, 東京, 1989 .

12) 小林清志, 飯田嘉宏: 新版 移動論, 第 13 版, 朝倉書店, 東京, 2000.

13) DeMore, W. B., Sander, S. P., Hampson, R. F., Kurylo, M. J., Golden, D. M., Howard, C. J., Ravishankara, A. R. and Molina, M. J.: Chemical Kinetics and Photochemical Data for Use in Stratospheric Modeling, Evaluation Number 9, Jet Propulsion Laboratory, JPL Publication 90-1, Pasadena, 1997.

14) Sander, S. P., Golden, D. M., Kuryio, M. J., Moortagat, G. K., Ravishankara, A. R., Kolb, C. E. and Molina, M. J.: Chemical Kinetics and Photochemical Data for Use in Atmospheric Studies, Evaluation Number 14, Jet Propulsion Laboratory, JPL Publication 02-25, Pasadena, 2003.

15) NIST (National Institute Standards and Technology) Chemical Kinetics Data Base on Web, http://kinetics.nist.gov/

16) 本田俊樹, 山極芳樹：打ち上げロケット排出物による「電離層の 穴」解析モデルの改善に関する研究, 日本航空宇宙学会論文集, 50 (2002), pp. 150-157.

17) Fujita, M., Aoki, H., Hattori, A., Nakagawa, T., Tokunaga, T., Yasui, M. and Iwama, K.: Upper Stage Propulsion System for H-IIA Launch Vehicle, 38th AIAA/ASME/SAE/ ASEE Joint Propulsion Conference and Exhibit, AIAA Paper 2002-4212, 2002. 